\title{
Humped-back shaped response of plant species richness to increasing shrub encroachment in calcareous grasslands
}

\author{
S. Kesting 1,2 , U. Petersen $1,3,4$ and J. Isselstein ${ }^{1}$ \\ ${ }^{1}$ Department of Crop Sciences, University of Göttingen, Von-Siebold-Str. 8, 37075 Göttingen, Germany \\ 2Saxon State Office for Environment, Agriculture and Geology, Department of Plant Production, Christgrün 13, \\ 08543 Pöhl, Germany \\ 3 Johann Heinrich von Thünen Institute of Climate Smart Agriculture, Bundesallee 60, 38116 Braunschweig, Germany \\ ${ }^{4}$ Corresponding author.Email: Ute_Petersen@gmx.net
}

Keywords: $\alpha$-diversity, $\gamma$-diversity, Habitat heterogeneity, Semi-natural grassland, Shrub cover, Shrub invasion, Species accumulation curve

\begin{abstract}
In the present study, we examined the effect of shrub encroachment in temperate semi-natural grasslands on plant species diversity. We tested the hypothesis that an initial shrub encroachment leads to enhanced habitat heterogeneity and thereby to a higher diversity. In a calcareous grassland near Göttingen (Germany) we analysed the effect of shrub encroachment on the species richness in $30,100 \mathrm{~m}^{2}$ plots each with 10 subplots of $1 \mathrm{~m}^{2}$ size. The 30 main plots belonged to six different shrub encroachment classes. A descriptive correlative gradient analysis of shrub invaded grasslands and their species number of flowering plants was performed. Within the 30 plots of different shrub encroachment a total of 203 plant species were recorded. The mean $\alpha 1$-diversity (level of subplots), mean $\alpha 2$-diversity (level of plots) as well as the $\alpha 3$-diversity (level of shrub encroachment classes) have their highest values at medium shrub invaded sites. This finding is in line with our hypothesis of a hump-back relation between shrub encroachment and species richness, and can be explained by the increased habitat heterogeneity. However, Detrended Correspondence Analysis (DCA) emphasized the importance of the present vegetation composition for species richness. The dominance of highly competitive, clonal-growing grass species is accompanied by low diversity swards with a lower facilitation of shrub establishment. Species accumulation curves highlight the benefit of shrub encroachment for $\gamma$-(landscape-) diversity. This result emphasises the importance of habitat heterogeneity for biodiversity and, therefore, nature conservation.
\end{abstract}

Nomenclature: Wisskirchen and Haeupler (1998) for vascular plants

Abbreviations: DCA - Detrended Correspondence Analysis, GLM-Generalized Linear Model.

\section{Introduction}

Semi-natural temperate grasslands are among the community types hosting the highest small-scale biodiversity not only in Europe (Pärtel et al. 2005, Dengler et al. 2014) but all over the world (Wilson et al. 2012). Those grasslands are strongly affected by abandonment of agricultural management. In consequence, woody plants invade the grassland and the area of typical species rich vegetation decreases (Dierschke 2006, Galvanek and Leps 2008, Dzwonko 2011, Ratajczak 2012, Habel et al. 2013). To preserve such habitats of high ecological value, maintenance of grassland management is required. To maintain species richness of forbs in dry-mesophilous meadows, Valkó et al. (2012) suggest, for example, a spatial and temporal mosaic of mowing practices.

Shrub encroachment of semi-natural grasslands is commonly perceived as having a negative effect on biodiversity and on nature conservation in particular, as rare species are threatened from extinction (e.g., Poschlod and WallisDeVries 2002, Valkó et al. 2012). The above mentioned observations are in contradiction with the mosaic concept of Duelli (Duelli
1992, 1997) and the habitat heterogeneity hypothesis in general (MacArthur and Wilson 1967). According to these theories, shrub invasion, at least during the initial stage when shrub cover is significantly below $100 \%$, can lead to higher habitat heterogeneity and therefore to higher biodiversity. This perspective is driven by ecological thinking rather than conservation of rare species. From a conservationist's point of view, a stable state of high landscape biodiversity is highly desirable. Since shrub encroachment is a dynamical process, a proper management of shrub cover is required. Consequently, more accurate information about the response of landscape biodiversity to shrub encroachment of seminatural grasslands will allow a more effective management to protect biodiversity.

The presented work investigates the influence of shrub encroachment on the species diversity of calcareous grasslands. The following hypotheses are proposed: 1) An initial shrub invasion leads to enhanced habitat heterogeneity and thereby to a higher diversity. 2) At later stages, that is after a certain degree of shrub encroachment, biodiversity will decline. 


\section{Methods}

\section{Study area}

The study area, the Kerstlingeröder Feld, is situated in the north-east of Göttingen, Lower Saxony, Germany (51 $52^{\prime}-$ $51^{\circ} 55^{\prime} \mathrm{N}, 10^{\circ} 0^{\prime} \mathrm{E} ; 300-375 \mathrm{~m}$ a.s.l). The area was used for military purposes from the early 20th century until 1993 and it, thus, passed the last century without agricultural intensification. This is also reflected in its low exchangeable soil phosphorus contents $(\leq 3.0 \mathrm{~g} / 100 \mathrm{~g}$ dry soil, calcium ammonium acetate extraction). Since 2004, it has been a nature reserve. Within an area of approximately 200 ha, the soil conditions and former land use history (i.e., extensive management) are relatively homogeneous. Still, there is a certain range of extensively managed or abandoned grasslands, ranging from rudimental semi-dry chalk grasslands (Gentiano-Koelerietum pyramidatae) and grasslands of the class Molinio-Arrhenatheretea (Lolio-Cynosuretum), to more or less unmanaged and shrub-invaded types linking to forest edges (Trifolion medii) and shrub vegetation (Prunetalia) with an average species richness of $17 / \mathrm{m}^{2}$. The grasslands of the Kerstlingeröder Feld host about one third of the total number of vascular plant species of the region around Göttingen (Garve 2007, own data). The main woody species are Crataegus spp., Rosa canina, Fraxinus excelsior and Cornus sanguinea. The soils are Cambisols with a small proportion Leptosol (Rendzina) on calcareous rock. The long-term mean annual temperature for the study area is $8.7^{\circ} \mathrm{C}$ and the mean annual precipitation is $645 \mathrm{~mm}$ (station Göttingen, $167 \mathrm{~m}$ a.s.1.). However, the Kerstlingeröder Feld is situated about 100-200 $\mathrm{m}$ above this station. Since the adiabatic gradient implies that temperatures decrease with height in mountains and in addition, topography enhances the uplift of moist air triggering condensation and precipitation (Barry 2008), the mean annual temperature is about $0.7^{\circ} \mathrm{C}$ lower whereas the precipitation is slightly higher than in Göttingen.

\section{Experimental design and measurements}

The main aim of the study was to analyse grassland species richness patterns along a shrub cover gradient. The amount of shrub cover is likely to be related to the successional stage, however, we are aware that shrub cover is not an exact measure to characterise the temporal dynamics of a succession. Within the predetermined geographical area, 30 plots $(10 \mathrm{~m} \times 10 \mathrm{~m})$ were selected along a shrub cover gradient $(\%)$, based on a time series of aerial photographs. Our aim was to represent a wide range of shrub encroachment from nearly shrub-free grasslands to sites with very dense shrub cover. As an extreme, we included one abandoned site that can be characterized as a pioneer forest on former calcareous grassland.

Because of different shrub height, we measured the intensity of shrub occurrence as a combination of percentage cover and maximum canopy height $(\mathrm{cm})$ as follows: shrub index $=\ln (1+$ cover $*$ canopy height $)$

A shrub index of 8 therefore results from $15 \%$ cover and 200 cm canopy height as well as $25 \%$ cover and $120 \mathrm{~cm}$ canopy height. As the shrub index represents the shrub volume, it is a better indicator of the competition for light than shrub cover only. For single calculations, plots were aggregated by ascending shrub index into 6 shrub classes, each containing 5 plots.

The botanical composition was measured in June. Within each plot, ten subplots of $1 \mathrm{~m}^{2}$ were positioned randomly. For each subplot, the occurrence of vascular plants was listed (presence-absence data). Abundance data at plot level arise from the presence-absence data by calculating the frequency. Phanerophytes are included, if they extended into the space above the quadrate. In the case of Ranunculus auricomus agg., Ranunculus polyanthemos agg., Rubus fruticosus agg. and Taraxacum sect. Ruderalia, identification ended with species aggregates.

Ten soil samples $(0-5 \mathrm{~cm}$ and 5-10 $\mathrm{cm}$ depth) were taken randomly and pooled per plot and analysed for $\mathrm{pH}$ (measured in $\mathrm{CaCl}_{2}$ ), exchangeable phosphorus and potassium (calcium ammonium acetate extraction).

\section{Data analysis}

Detrended Correspondence Analysis was used to explore the influence of vegetation composition on the dependency detected by the regression model. The analysis was performed on the log-transformed species abundance matrix with detrending by-segments and down-weighting of rare species using program Canoco (ter Braak and Šmilauer 2002). Species richness was fitted by a Generalized Linear Model (GLM, quadratic degree) and visualised in the DCAplot by isolines.

The $\alpha$-diversity was calculated according to Whittaker (1972) as number of species per given area. Since our experimental units comprised three different scales (subplot, plot and shrub class), we had to distinguish between three levels of $\alpha$-diversity: within subplot $(\alpha 1)$, within plot $(\alpha 2)$ and within shrub class $(\alpha 3)$.

Likewise, the $\gamma$-diversity was defined as total number of species in the experimental area. The influence of shrub encroachment on $\gamma$-diversity was estimated using species accumulation curves. Species accumulation curves are calculated for single ordering of samples (ordered by shrub index) on the one hand and on the other hand as means of repeated resampling of all pooled samples (1000-fold resampling). The second is according to the sample-based rarefaction curve in terms of Gotelli and Colwell (2001). The 95\% confidence interval is the range which contains $95 \%$ of the values.

Differences in species number per plot and subplot as well as differences in soil parameters between shrub classes were tested by analysis of variance (ANOVA). Accumulation curves and ANOVA were computed using program R ( R Development Core Team 2008). 


\section{Results}

\section{Shrub encroachment and vegetation composition}

The vegetation in the present study covered a gradient of shrub encroachment from shrub-free grasslands to pioneer forest vegetation. The canopy height of the shrub vegetation was usually between 15 and $500 \mathrm{~cm}$ (pioneer forest with $1000 \mathrm{~cm}$ ), and the canopy cover ranged from less than $1 \%$ to nearly $100 \%$. The values of the calculated shrub index ranged from 0 to 11.4 with a mean of 6.4 .

Caused by the wide gradient of shrub encroachment, the vegetation composition varied significantly between the plots. With further shrub encroachment, the relative number of woody species increased from 4.2 to $25.2 \%$, dominated by Crataegus spp., Rosa canina, Fraxinus excelsior and Cornus sanguinea. The most frequent grass species were Dactylis glomerata, Festuca rubra and Poa pratensis. With increasing shrub encroachment, Trisetum flavescens and Brachypodium pinnatum became more abundant. The most frequent forbs were Galium album, Plantago lanceolata, Veronica chamaedrys, Fragaria vesca and Taraxacum sect. Ruderalia. With increasing shrub encroachment, there
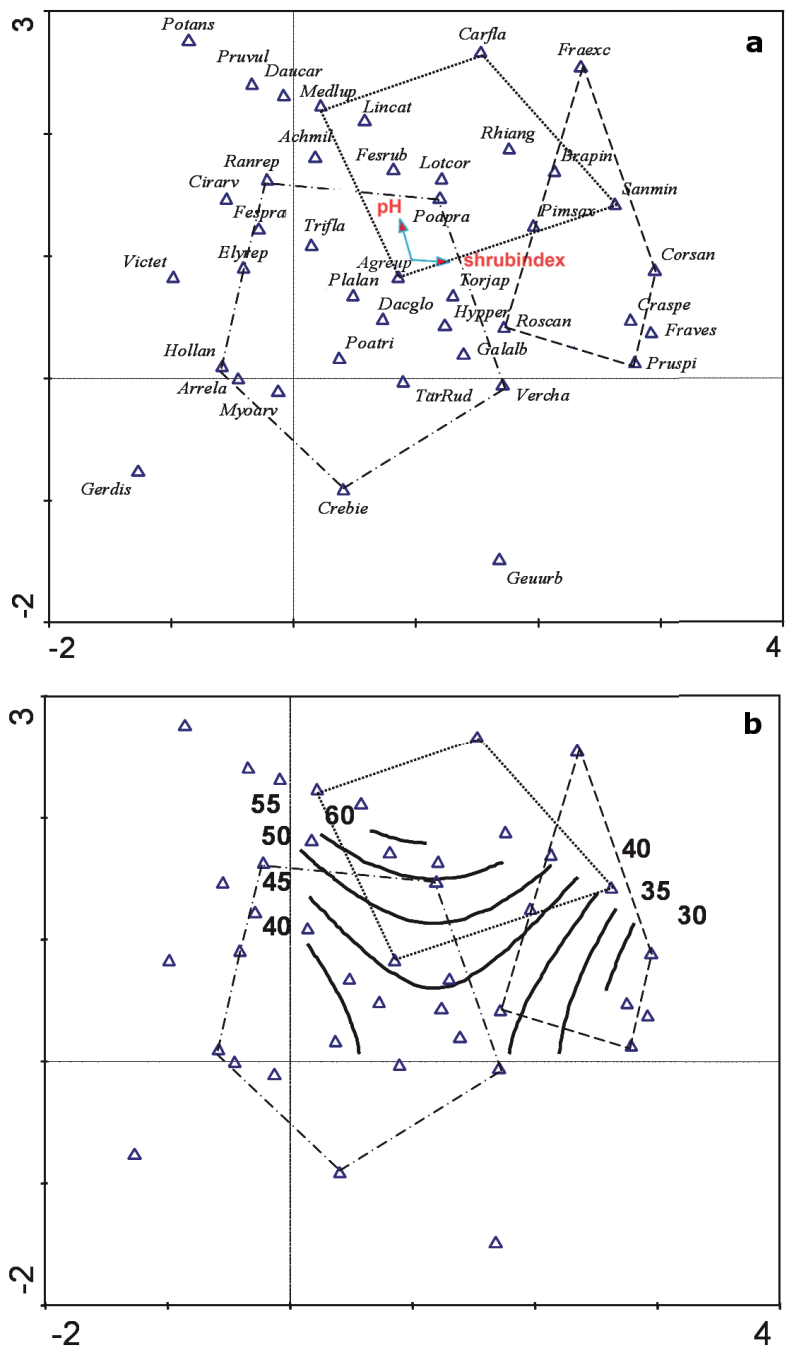

was a decrease in the ratio of grass species to forbs from 0.56 to 0.39 , and a decrease in the proportion of the number of legume species from 0.157 to 0.046 , averaged over shrub classes.

In Figure 1, the DCA biplot demonstrates the variability in vegetation composition. The length of the gradient for the first axis is $2.9 \mathrm{SD}$. The location of woody species in the plot suggests that the first axis represents the gradient of shrub occurrence. Shrubs and trees have relatively high species scores for the first axis $(>1.72)$, whereas typical species of mesophilous grasslands have species scores between -0.45 and 1.70. Calcareous grassland species have intermediate scores, but are distinguished from mesophilous grassland species by a higher score for the second axis. The calcareous grassland species were associated with a higher $\mathrm{pH}$, the shrub and tree species with a higher shrub index (Figure 1a).

\section{Species diversity}

The vegetation had relatively high numbers of vascular plant species at all examined spatial scales. In total, we found 203 vascular plant species. The number of species per plot ranged between 27 and $68($ mean $=44.5)$. Maximum recorded

Figure 1. DCA ordination plots (axis 1 (eigenvalue 0.385 ) and 2 (eigenvalue 0.195)) based on 30 samples of grassland vegetation. a: Plant species with highest fit are displayed and grouped by sociological behaviour. Legend: -.-.-• mesophilous grassland species, … calcareous grassland species, --- shrubs and trees. b: Isolines of similar species richness (-) result from a fitted generalized linear model (quadratic degree).

Species codes: Achmil $=$ Achillea millefolium, Agreup $=$ Agrimonia eupatoria, Arrela $=$ Arrhenatherum elatius, Brapin $=$ Brachypodium pinnatum, Carfla $=$ Carex flacca, Cirarv $=$ Cirsium arvense, Corsan $=$ Cornus sanguinea, Craspe $=$ Crataegus monogyna, Crebie $=$ Crepis biennis, Dacglo $=$ Dactylis glomera ta , Daucar $=$ Daucus carota, Elyrep $=$ Elymus repens, Fespra $=$ Festuca pratensis, Fesrub $=$ Festuca rubra, Fraves $=$ Fragaria vesca, Fraexc $=$ Fraxinus excelsior , Galalb $=$ Galium album, Gerdis $=$ Geranium dissectum, Geuurb = Geum urbanum, Hollan $=$ Holcus lanatus, Hypper $=$ Hypericum perforatum, Lincat $=$ Linum catharticum, Lotcor $=$ Lotus corniculatus, Medlup = Medicago lupulina, Myoarv = Myosotis arvensis, Pimsax $=$ Pimpinella saxifraga, Plalan $=$ Plantago lanceolata , Poapra $=$ Poa pratensis, Poatriv $=$ Poa trivialis, Potans $=$ Potentilla anserina, Pruvul $=$ Prunella vulgaris, Pruspi $=$ Prunus spinosa , Ranrep $=$ Ranunculus repens, Rhiang $=$ Rhinanthus angustifolius, Roscan $=$ Rosa canina, Sanmin $=$ Sanguisorba minor, TarRud $=$ Taraxacum sect . Ruderalia, Torjap $=$ Torilis japonica, Trifla $=$ Trisetum flavescens, Vercha = Veronica chamaedrys, Victet $=$ Vicia tetrasperma . 
A

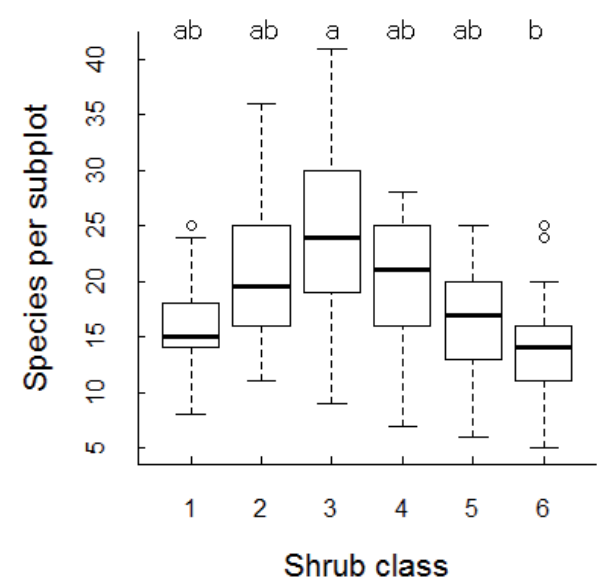

B

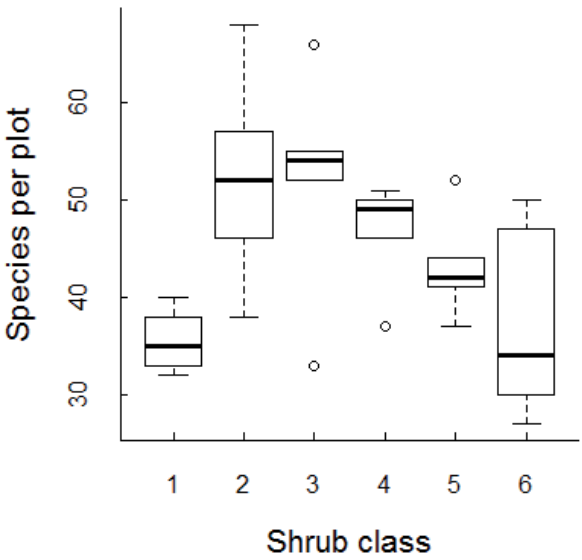

Figure 2. Number of vascular plant species (A) per subplot ( $\alpha 1$-diversity) and (B) per plot ( $\alpha 2$-diversity) according to increasing shrub encroachment (each shrub class contains 5 plots). Shrub classes with different letter differ significantly according to a comparison of means using Tukey's 'Honest Significant Difference' method $(\alpha=0.05)$.
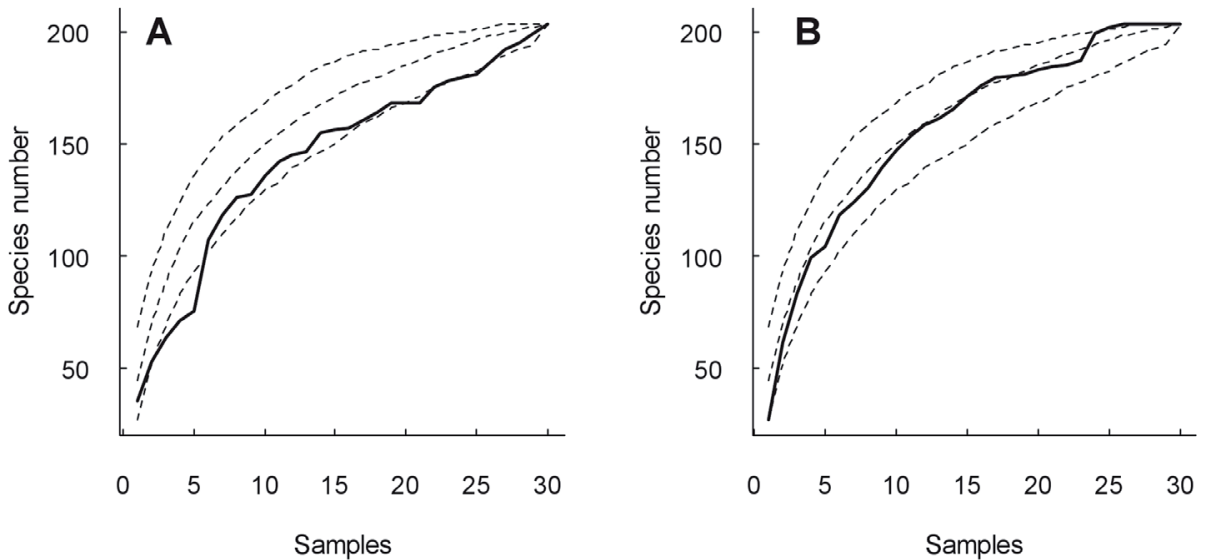

Figure 3. Species accumulation curves. Presented are the expected species accumulation curves (----) with $95 \%$ confidence intervals, calculated by 1.000 -fold resampling and the measured species accumulation curves (---) with defined sample order. A: by ascending shrub index, B: by descending shrub index.

species number per $\mathrm{m}^{2}$ (subplot) was $41($ mean $=17)$. Highest species richness was found at medium shrub invaded sites. The mean $\alpha 1$ - diversity (level of subplots), mean $\alpha 2$-diversity (level of plots) as well as the $\alpha 3$-diversity (level of shrub classes) had their highest values at shrub class three (shrub index of 4.5 - 5.8). Although the ANOVA identified shrub class as significant factor influencing species richness at subplot and plot level $(P=0.049$ and $P=0.021)$ the following post-hoc test showed that differences in mean species numbers between shrub classes were, however, not significant, except for a significant difference between shrub classes 3 and 6 (Figure 2).

In the DCA, the species number was fitted by a generalized linear model (GLM) and visualized by isolines in the DCA biplot (Figure 1b). The highest species numbers were found at plots with intermediate values for the first axis and high values for the second. These plots are characterized by high proportions of calcareous grassland species.
To assess the effect of shrub encroached grassland sites on $\gamma$-diversity, species accumulation curves have been computed (Figure 3). The 'smoothed' curves represent the means of 1000-fold resampling of all pooled samples (sample-based rarefaction curve) with $95 \%$ confidence interval. The solid lines are species accumulation curves for ordering of samples by shrub index. The species accumulation curve and the rarefaction curve are very similar, if samples are ordered by descending shrub index (Figure 3b). If samples are ordered by ascending shrub index, the accumulation curve is close to or even lower than the $95 \%$ confidence interval (Figure 3a). This means that the species accumulation curve and the sample-based rarefaction curve differ significantly by a probability value of $5 \%$, i.e., their slopes differ. At the beginning when only samples with a low shrub index are added (samples 0-10), the incline of the slope of the accumulation curve is not as steep as the incline of the calculated curve, which means that less species than expected are added with each new sample. Since both curves share the same starting and 
Table 1. Soil variables $\mathrm{pH}$, phosphorus $(\mathrm{P})$ and potassium $(\mathrm{K})$ measured in $0-5 \mathrm{~cm}$ soil depth. Values are the mean and standard deviation averaged across shrub classes. Differences between the shrub classes were tested using ANOVA $(\alpha=0.05)$. Significant values are printed in bold.

\begin{tabular}{|c|c|c|c|}
\hline Shrub class & $\mathrm{pH}$ & $\begin{array}{c}P \\
(\mathrm{~g} / 100 \mathrm{~g} \mathrm{DM})\end{array}$ & $\begin{array}{c}\mathrm{K} \\
(\mathrm{g} / 100 \mathrm{~g} \mathrm{DM})\end{array}$ \\
\hline 1 & $6.24 \pm 0.75$ & $3.59 \pm 1.77$ & $20.0 \pm 3.5$ \\
\hline 2 & $7.26 \pm 0.15$ & $1.57 \pm 1.17$ & $21.3 \pm 7.1$ \\
\hline 3 & $6.84 \pm 0.46$ & $2.79 \pm 2.81$ & $19.9 \pm 2.9$ \\
\hline 4 & $6.78 \pm 0.65$ & $2.21 \pm 1.43$ & $21.3 \pm 5.8$ \\
\hline 5 & $6.64 \pm 0.55$ & $1.58 \pm 0.66$ & $26.2 \pm 3.6$ \\
\hline 6 & $6.10 \pm 0.17$ & $2.90 \pm 1.99$ & $26.2 \pm 7.2$ \\
\hline $\mathrm{F}$ value & 3.46 & 1.02 & 1.53 \\
\hline Sign. (P) & 0.02 & 0.43 & 0.22 \\
\hline
\end{tabular}

end points, the incline of the measured curve becomes steeper in the end when samples with the highest shrub indices are added. For instance, the ten samples with highest shrub index accounted for 35 additional species, whereas the theoretical rarefaction curve predicted only 18 additional species. This indicates a diversity benefit above average from the samples with high shrub index.

Soil variables were measured to characterize the site conditions of the plots. Except for $\mathrm{pH}$, no significant differences were found between them at the level of shrub classes for both, 0-5 cm (Table 1) and 5-10 cm soil depth (data not shown).

\section{Discussion}

Due to the lack of agricultural intensification during the last century, the studied grasslands remained agriculturally unaltered, semi-natural grasslands. Although these grasslands belong to different phytosociological classes, the vegetation composition of the experimental plots is quite homogeneous when measured as standard deviation of species turnover (SD, unit of gradient length) in DCA. The length of the first gradient, 2.9 SD, is well below 4.0 SD which would indicate a complete species turnover, i.e., at least two plots have no species in common (Hill and Gauch 1980).

The vegetation had relatively high numbers of vascular plant species. The maximum of 41 species per $\mathrm{m}^{2}$ corresponds to other species-rich calcareous grasslands (Kull and Zobel 1991; Klimek et al. 2007; Wilson et al. 2012). Highest numbers of plant species were found at medium shrub invaded sites, which is in line with our hypothesis of a humpback relation between shrub encroachment and species richness. A similar result has been reported from semi- natural grasslands in SW Finland (Pykälä et al. 2005). The authors found the highest species richness with a tree cover of ca. $5 \%$. Further increasing cover of trees had a negative effect on species richness, which was mainly attributed to a reduced light availability. Pihlgren and Lennartsson (2008) analysed the effect of shrubs of Rosa dumalis on grassland plants in semi-natural pastures in Sweden. They found that the net ef- fect of shrubs in semi-natural grassland is neutral or positive rather than negative for most plant species. This means that the number of species which responded positively to shrubs was comparable to the number of species which had a negative response. Total species richness was, therefore, not significantly affected by the shrubs.

In relation to the species richness we found a higher phosphorus content limiting the number of species per plot. Plots with more than 40 species had phosphorus contents below $2.55 \mathrm{~g} / 100 \mathrm{~g}$ DM in the fraction of $0-5 \mathrm{~cm}$ depth.

In the present study, strong influence on species richness could be attributed to the vegetation composition. In general, plots which were dominated by mesophilous grassland species were less diverse than plots with a higher abundance of calcareous grassland species. Calcareous grassland species are less competitive and better adapted to dry and nutrient poor conditions (stress tolerators) compared to mesophilous grassland species (Grime 2001). These species are often target species for nature conservation. A loss of those species during successional processes refers to the dominance of highly competitive, usually clonal-growing, tall plants. This fact has also been reported by Valkó et al (2011), who compared species composition in managed and long time abandoned dry-mesophilous and fen meadows. In the present study, we found Arrhenatherum elatius, Holcus lanatus, Elymus repens and Poa trivialis characterizing plots with relatively low species numbers as well as low intensity of shrub encroachment. This can be explained by different pathways of succession. Shrub establishment and encroachment are not necessarily straightforward processes of grassland succession. Shrub establishment depends on several local factors like site history, availability of propagules and safe-sites for the seed germination (e.g., van Auken 2000, Prach 2006, Řehounková and Prach 2006, Zavaleta 2006, Dölle et al. 2008). Dense swards of clonal-growing grass species and high litter depth impede the germination of shrub and tree species. The dense grass canopy can persist for more than 20 years and inhibits shrub or tree development (Schreiber 1995, Prach et al. 2001).

Several studies on calcareous grassland succession focus on the grass species Brachypodium pinnatum. It has been ascribed as an aggressive species of calcareous grasslands with increasing dominance and the ability to decrease species diversity during secondary succession (Bobbink and Willems 1987, Willems 2001). It is therefore of some interest that the occurrence of Brachypodium pinnatum in the present study was related to more diverse vegetation.

The influence of shrub encroachment on $\gamma$-diversity was estimated using species accumulation curves. Our results show a considerable increase of total species richness ( $\gamma$-diversity) due to the plots with a high shrub index. For the purpose of enhancing biodiversity, this seems to be a positive aspect of shrub encroachment. Nevertheless, we have no valid information about the $\gamma$-diversity of the whole study area, and how the selected grassland plots contribute to it. A floristic mapping project detected more than 600 vascular plant species per 5.5 by $5.5 \mathrm{~km}^{2}$ in this region (Garve 2007), which is more than three times the species we found. Our 
study is certainly a representative sample of the prevailing grassland vegetation of this area but lacks other vegetation units particularly the forest vegetation. The positive influence of shrub encroachment on $\gamma$-diversity detected in our study could probably be similarly observed by addition to other vegetation types, which were not examined.

The spatial distribution of the shrubs can be clumped (patchy) or more or less homogeneous. Border structures feature specialized biocoenosis and are known for their importance for nature conservation (Hondong et al. 1993, Kollmann and Poschlod 1997). Transition from grassland to wood forms fringe community types, of which Trifolio medii-Agrimonietum eupatoriae dominated in the present study. The patchier the mosaic of shrubs growing in grassland, the higher is the proportion of border structures, and the higher is the potential value for nature conservation. The spatial extend or length of border structures should be taken into account, if shrub encroachment of grassland is evaluated in further research.

From the present study, a general question arises. Shrub encroachment characterizes a phenological stage of succession. However, the extent of shrub establishment is neither a measure of succession nor a correlate to the time since abandonment. This is due to the different possible pathways and the stochastic character of succession (Prach 2006). Even under experimental conditions, shrub establishment as the first step of secondary succession occurred with probability rates below $0.1 \%$, as Zavaleta (2006) demonstrated in a field experiment in a Californian grassland. Therefore, the results of this study underline the importance of cover- rather than time-based shrub clearance.

It is evident that abandonment of species-rich grasslands will cause a decrease in species richness on the long run (Dierschke 2006, Galvanek and Lepš 2008, Mitlacher et al. 2002, Valkó et al. 2011). Even a total clearance of all woody species is of no use without further management (e.g., pasture). The woody canopy can be re-established within the course of only three years (Novák et al. 2013). The finding of this study that slight shrub encroachment benefits species richness, was driven by the cross-sectional study design and the focus on broader spatial scales. Plots with shrub encroachment to a certain degree (the corresponding shrub class 3 can also be expressed as $5 \%$ shrub cover with a height of $20 \mathrm{~cm}$ up to $60 \mathrm{~cm}$ ), were found to have highest species numbers. Furthermore, we found the $\gamma$-diversity of the studied grassland sites positively influenced by plots with higher shrub occurrence. Hence, a mosaic of more or less shrub encroached grassland patches should be made conservation aim, managed e.g., by large scale pasture or by creation of a mosaic of regularly and infrequently mown patches. A total clearance of all shrubs in a given area will decrease the $\gamma$-diversity.

\section{References}

Barry, R.G. 2008. Mountain Weather and Climate. 3rd ed. Cambridge University Press, Cambridge, UK.

Bobbink, R. and Willems, J.H. 1987. Increasing dominance of Brachypodium pinnatum (L.) Beauv. in chalk grasslands - a threat to a species-rich ecosystem. Biol. Conserv. 40: 301-314.
Dengler, J., Janišová, M., Török, P. and Wellstein, C. 2014. Biodiversity of Palaearctic grasslands: a synthesis. Agr., Ecosyst. Environ. 182: 1-14.

Dierschke, H. 2006. Secondary progressive succession of an abandoned calcareous grassland - research on permanent plots $1987-$ 2002. Hercynia N. F. 39: 223-245.

Dölle, M., Bernhardt-Römermann, M., Parth, A. and Schmidt, W. 2008. Changes in life history trait composition during undisturbed old-field succession. Flora - Morphology, Distribution, Functional Ecology of Plants 203: 508-522.

Duelli, P. 1997. Biodiversity evaluation in agricultural landscapes: An approach at two different scales. Agr., Ecosyst. Environ. 62: 81-91.

Duelli, P. 1992. Mosaikkonzept und Inseltheorie in der Kulturlandschaft. Verhandlungen der Gesellschaft für Ökologie 21: 379-383.

Dzwonko, Z. 2011. Effect of changes in land use during the 20th century on woodland and calcareous grassland vegetation in southern Poland. Folia Biologica et Oecologica 7, 27p.

Galvanek, D. and Lepš, J. 2008. Changes of species richness pattern in mountain grasslands: abandonment versus restoration. Biodivers. Conserv. 17: 3241-3253.

Garve, E. 2007. Verbreitungsatlas der Farn- und Blütenpflanzen in Niedersachsen und Bremen. Nieders. Landesbetrieb für Wasserwirtschaft, Küsten- und Naturschutz, Hannover.

Gotelli, N.J. and Colwell, R.K. 2001. Quantifying biodiversity: procedures and pitfalls in the measurement and comparison of species richness. Ecol. Lett. 4: 379-391.

Grime, J.P. 2001. Plant Strategies, Vegetation Processes, and Ecosystem Properties. 2nd ed. Wiley, Chichester, UK.

Habel, J.C., Dengler, J., Janišová, M., Török, P., Wellstein, C. and Wiezik, M. 2013. European grassland ecosystems: threatened hotspots of biodiversity. Biodiv. Conserv. 22: 2131-2138.

Hill, M.O. and Gauch, H.G. 1980. Detrended correspondence analysis: An improved ordination technique. Plant Ecol. 42: 47-58.

Hondong, H., Langner, S. and Coch, T. 1993. Untersuchungen zum Naturschutz an Waldrändern. Bristol-Schriftenreihe 2: $196 \mathrm{~S}$.

Klimek, S, Kemmermann, A.R., Hofmann, M. and Isselstein, J. 2007. Plant species richness and composition in managed grasslands: The relative importance of field management and environmental factors. Biol. Conserv. 134: 559-570.

Kollmann, J. and Poschlod, P. 1997. Population processes at the grassland-scrub interface. Phytocoenologia 27: 235-256.

Kull, K. and Zobel, M. 1991. High species richness in an Estonian wooded meadow. J. Veg. Sci. 2: 715-718.

MacArthur, R.H. and Wilson, E.O. 1967. The Theory of Island Biogeography. Princeton University Press, Princeton, USA.

Mitlacher, K., Poschlod, P., Rosen, E. and Bakker, J.P. 2002. Restoration of wooded meadows - a comparative analysis along a chronosequence on Oland (Sweden). Appl. Veg. Sci. 5: 63-73.

Novák, J., Pavlů, V. and Ludvíková, V. 2013. Reintroduction of grazing management after deforestation of formerly abandoned grassland and its effect on early vegetation changes in the Western Carpathians (Slovakia). Grass Forage Sci. 68: 448458.

Pärtel, M., Bruun, H.H. and Sammul, M. 2005. Biodiversity in temperate European grasslands: origin and conservation. Grassl. Sci. Europe 10: 1-14. 
Pihlgren, A. and Lennartsson, T. 2008. Shrub effects on herbs and grasses in semi-natural grasslands: positive, negative or neutral relationships? Grass Forage Sci. 63: 9-21.

Poschlod, P. and WallisDeVries, M.F. 2002. The historical and socioeconomic perspective of calcareous grasslands-lessons from the distant and recent past. Biol. Conserv. 104: 361-376.

Prach, K., Pyšek, P. and Bastl, M. 2001. Spontaneous vegetation succession in human-disturbed habitats: A pattern across seres. Appl. Veg. Sci. 4: 83-88.

Prach, K. and Řehounková, K. 2006. Vegetation succession over broad geographical scales: which factors determine the patterns? Preslia 78: 469-480.

Pykälä, J., Luoto, M., Heikkinen, R.K. and Kontula, T. 2005. Plant species richness and persistence of rare plants in abandoned semi-natural grasslands in northern Europe. Basic Appl. Ecol. 6: 25-33.

Ratajczak Z., Nippert J.B. and Collins S.L. 2012. Woody encroachment decreases diversity across North American grasslands and savannas. Ecology 93: 697-704

R Development Core Team 2008. R: A language and environment for statistical computing. R Foundation for Statistical Computing, Vienna, Austria.

Řehounková, K. and Prach, K. 2006. Spontaneous vegetation succession in disused gravel-sand pits: Role of local site and landscape factors. J. Veg. Sci. 17: 583-590.

Schreiber, K. 1995. Renaturierung von Grünland - Erfahrungen aus langjährigen Untersuchungen und Managementmaßnahmen. Berichte der Reinhold-Tüxen-Gesellschaft 7: 111-140.

ter Braak, C.J.F. and Šmilauer, P. 2002. CANOCO reference manual and CanoDraw for Windows user's guide: Software for canoni- cal community ordination (version 4.5). Microcomputer Power, Ithaca NY, USA.

Valkó, O., Török, P., Tóthmérész, B. and Matus, G. 2011. Restoration potential in seed banks of acidic fen and dry-mesophilous meadows: Can restoration be based on local seed banks? Restor. Ecol. 19: 9-15.

Valkó, O., Török, P., Matus, G. and Tóthmérész, B. 2012. Is regular mowing the most appropriate and cost-effective management maintaining diversity and biomass of target forbs in mountain hay meadows? Flora-Morphology, Distribution, Funct. Ecol. Plants 207: 303-309.

van Auken, O.W. 2000. Shrub invasions of North American semiarid grasslands. Ann. Rev. Ecol. Syst. 31: 197-215.

Whittaker, R.H. 1972. Evolution and measurement of species diversity. Taxon 21: 213-251

Willems, J.H. 2001. Problems, approaches, and, results in restoration of Dutch calcareous grassland during the last 30 years. Restor. Ecol. 9: 147-154.

Wilson, J.B., Peet, R.K., Dengler, J. and Pärtel, M. 2012. Plant species richness: the world records. J. Veg. Sci. 23: 796-802.

Wisskirchen, R. and Haeupler, H. 1998. Standardliste der Farnund Blütenpflanzen Deutschlands. Ulmer, Stuttgart, Germany.

Zavaleta, E. 2006. Shrub establishment under experimental global changes in a California grassland. Plant Ecol. 184: 53-63.

Received March 16, 2015

Revised May 10, 2015

Accepted August 27, 2015 